\title{
Construction of a Restriction Map of the Gluconobacter Bacteriophage A-1 Genome
}

\author{
By N.K. ROBAKIS, ${ }^{1 *}$ N. J. PALLERONI, ${ }^{2}$ M. BOUBLIK ${ }^{3}$ AND \\ C. W. DESPREA UX ${ }^{2}$ \\ ${ }^{1}$ New York State Office of Mental Retardation and Developmental Disabilities, Institute for \\ Basic Research in Developmental Disabilities, 1050 Forest Hill Road, Staten Island, ' \\ NY 10314, USA \\ 2 Department of Microbiology, Hoffmann-La Roche Inc., Nutley, NJ 07110, USA \\ ${ }^{3}$ Roche Institute of Molecular Biology, Roche Research Center, Hoffmann-La Roche Inc., Nutley, \\ NJ 07110, USA
}

(Received 5 December 1984; revised 24 April 1985)

\begin{abstract}
The molecular weight of Gluconobacter bacteriophage A-1 DNA was determined by restriction analysis and electron microscopic measurements to be about $30 \times 10^{6}$. The DNA has cohesive ends and forms ring-like monomers. A circular map with the relative positions of the cleavage sites for the restriction enzymes EcoRI, SmaI, XhoI and BamHI is proposed.
\end{abstract}

\section{INTRODUCTION}

Members of the genus Gluconobacter carry out limited oxidations of alcohols and sugars resulting in high yields of industrially important products (Ward, 1967; Asai, 1968). In spite of the economic importance of these transformations, little is known at present about the physiology and genetics of the organisms involved. The isolation of the first bacteriophage specific for members of this genus (phage A-1) was reported recently (Schocher et al., 1979), as a result of studies of abnormalities found in the microbiological process for the oxidation of $D$ sorbitol to L-sorbose by Gluconobacter oxydans. Since then the isolation and characterization of two more Gluconobacter bacteriophages has been reported (Robakis et al., 1985). This communication describes the results of molecular characterization of the phage A-1 genome.

\section{METHODS}

Culture conditions. Strain J of Gluconobacter oxydans was obtained from the culture collection of Hoffmann-La Roche, Nutley, NJ, USA. The strain was grown in mannitol medium (Robakis et al., 1985). Bacteriophage A-1 was propagated on the bacterial strain using mannitol agar medium and was purified as described in the preceding paper (Robakis et al., 1985).

Isolation of phage DNA. SDS, EDTA ( $\mathrm{pH} \mathrm{8.0)}$ ) and proteinase $\mathrm{K}$ (Boehringer) were added to the phage A-1 suspension to give final concentrations of $0.5 \%(\mathrm{w} / \mathrm{v}), 20 \mathrm{mM}$ and $50 \mu \mathrm{g} \mathrm{ml}^{-1}$ respectively. The mixture was incubated $(1 \mathrm{~h})$ at $65^{\circ} \mathrm{C}$ and then extracted with an equal volume of phenol equilibrated with $100 \mathrm{~mm}$-Tris/ $\mathrm{HCl}$ buffer, pH 8.0. This step was followed by extractions with phenol/chloroform (1:1), and with chloroform. Finally, the DNA was dialysed against $10 \mathrm{mM}$-Tris/ $\mathrm{HCl}, \mathrm{pH} 8 \cdot 0,1 \mathrm{mM}$-EDTA, and stored at $4{ }^{\circ} \mathrm{C}$ (Maniatis et al., 1982).

Restriction analysis. The phage DNA was digested with various restriction enzymes (New England Biolabs) following the manufacturer's instructions. Double digestions were done by first incubating $5 \mu \mathrm{g}$ of DNA with one enzyme, followed by treatment of samples $(1 \mu \mathrm{g})$ of the digest with the second enzyme. The DNA fragments were separated by gel electrophoresis on $1 \%(\mathrm{w} / \mathrm{v})$ agarose gels, using a horizontal apparatus $(22 \times 13.5 \mathrm{~cm})$. The electrophoresis buffer, staining and visualization of the DNA bands are described in the preceding paper (Robakis et al., 1985). DNA fragments were isolated from the gels by electro-elution into dialysis bags. The eluted DNA was purified by passage through Elutip columns (Schleicher \& Schuell, Keene, NH, USA) according to the manufacturer's directions, and by ethanol precipitation. 
Electron microscopy. DNA extracted from the phage was spread at room and elevated temperatures $\left(37^{\circ} \mathrm{C}\right.$ and $75^{\circ} \mathrm{C}$ ) by the protein monolayer technique (Kleinschmidt, 1968), using cytochrome $c$. It was then air dried and contrasted by rotary shadowing with $\mathrm{Pt} / \mathrm{Pd}$. The specimens were examined with a JEM $100 \mathrm{~B}$ electron microscope operated at $80 \mathrm{kV}$. The length of the individual DNA molecules was determined as described in the preceding paper (Robakis et al., 1985).

\section{RESULTS AND DISCUSSION}

Cleavage by restriction endonucleases. Undigested phage A-1 DNA travelled on a $1 \%(\mathrm{w} / \mathrm{v})$ agarose gel as a single band more than $23 \mathrm{~kb}$ in length (data not shown). Treatment with $X$ hoI, $M l u \mathrm{I}$ and HindII yielded four, eight and 11 fragments respectively (Table 1). The sum of the lengths of these fragments indicate that the phage A-1 genome consists of a double stranded DNA molecule about $45 \mathrm{~kb}$ long. These conclusions are supported by electron microscopy (see below).

Construction of a partial restriction map of the phage A-1 genome. Phage A-1 DNA yields a limited number of fragments upon digestion with the enzymes XhoI, EcoRI, BamHI and SmaI. Therefore we attempted to construct a map containing the relative positions of the restriction sites of these enzymes.

Treatment of the XhoI digest with BamHI results in the disappearance of the $9 \mathrm{~kb}$ band and the appearance of three new bands $4.8,2.5$ and $2.0 \mathrm{~kb}$ long, indicating the presence of at least two cleavage sites for the BamHI enzyme. Digestion of the A-1 DNA with BamHI gives two bands, one over $23 \mathrm{~kb}$, and the other $2.5 \mathrm{~kb}$ long (Table 1). Treatment of the XhoI-digested DNA with EcoRI leads to the disappearance of the $20 \mathrm{~kb}$ and the $12 \mathrm{~kb}$ fragments, and to the appearance of five new fragments. This indicates that the A-1 genome contains at least three EcoRI restriction sites (Table 1). However, digestion of A-1 DNA with EcoRI yields three fragments, one over $23 \mathrm{~kb}$, one about $18 \mathrm{~kb}$ and one $1.5 \mathrm{~kb}$ long. Treatment of the $X$ hoI-digested DNA with $S m a I$ results in the disappearance of the largest $(20 \mathrm{~kb})$ and the smallest $(4 \mathrm{~kb})$ bands, and in the appearance of three new bands about $10.5,10$ and $3.5 \mathrm{~kb}$ long. A fourth fragment of about $0.4 \mathrm{~kb}$ (which should have been derived from the cleavage of the $4 \mathrm{~kb}$ fragment) was presumably electrophoresed off the gel. These data indicate that there are at least two SmaI restriction sites within the A-1 genome. Digestion of A-1 DNA with SmaI and EcoRI results in the appearance of five bands, while digestion with $S m a$ I and BamHI gives four fragments (Table 1). Treatment of the phage DNA with $E c o$ RI and BamHI yields four bands, 18, 6.3, 2.5 and $1.5 \mathrm{~kb}$ long. Since the A-1 DNA is about $45 \mathrm{~kb}$ long, the slowest moving band must contain two fragments of approximately equal length. The above results indicate that the phage A-1 DNA is a circular molecule, and are consistent with the restriction map shown in Fig. 1. The following experimental data are in agreement with the proposed partial restriction map: (a) isolation of

Table 1. Length $(k b)$ of fragments produced by the action of restriction endonucleases on phage A-1 DNA

\begin{tabular}{|c|c|c|c|c|c|c|c|c|c|c|c|c|}
\hline \multirow[b]{2}{*}{$\begin{array}{c}\text { Fragment } \\
\text { no. }\end{array}$} & \multicolumn{6}{|c|}{ Single digests by: } & \multicolumn{6}{|c|}{ Double digests by: } \\
\hline & HindII & $M l u \mathrm{I}$ & XhoI & $B a m \mathrm{HI}$ & EcoRI & $S m a I$ & $\begin{array}{l}\text { XhoI + } \\
\text { BamHI }\end{array}$ & $\begin{array}{c}\text { XhoI }+ \\
\text { EcoRI }\end{array}$ & $\begin{array}{c}\text { XhoI + } \\
\text { SmaI }\end{array}$ & $\begin{array}{c}E c o \mathrm{RI}+ \\
\text { Bam HI }\end{array}$ & $\begin{array}{c}\text { EcoRI+ } \\
\text { SmaI }\end{array}$ & $\begin{array}{c}\text { SmaI + } \\
\text { BamHI }\end{array}$ \\
\hline 1 & $17 \cdot 0$ & $12 \cdot 0$ & $20 \cdot 0$ & $>23$ & $>23$ & $>23$ & $20 \cdot 0$ & $13 \cdot 0$ & $12 \cdot 0$ & $18 \cdot 0$ & $23 \cdot 0$ & $17 \cdot 0$ \\
\hline 2 & $6 \cdot 0$ & $7 \cdot 0$ & $12 \cdot 0$ & $2 \cdot 5$ & $18 \cdot 0$ & $11 \cdot 0$ & $12 \cdot 0$ & $9 \cdot 0$ & $10 \cdot 5$ & $6 \cdot 3$ & $11 \cdot 0$ & $15 \cdot 0$ \\
\hline 3 & $5 \cdot 0$ & $6 \cdot 0$ & $9 \cdot 0$ & & 1.5 & & $4 \cdot 8$ & $8 \cdot 0$ & $10 \cdot 0$ & $2 \cdot 5$ & $6 \cdot 4$ & $11 \cdot 0$ \\
\hline 4 & $4 \cdot 0$ & $5 \cdot 5$ & $4 \cdot 0$ & & & & $4 \cdot 0$ & $6 \cdot 0$ & $9 \cdot 0$ & 1.5 & $3 \cdot 0$ & $2 \cdot 5$ \\
\hline 5 & $2 \cdot 9$ & $5 \cdot 0$ & & & & & $2 \cdot 5$ & $4 \cdot 3$ & 3.5 & & 1.5 & \\
\hline 6 & $2 \cdot 6$ & $4 \cdot 2$ & & & & & $2 \cdot 0$ & $4 \cdot 0$ & & & & \\
\hline 7 & $2 \cdot 3$ & $2 \cdot 3$ & & & & & & $1 \cdot 5$ & & & & \\
\hline
\end{tabular}




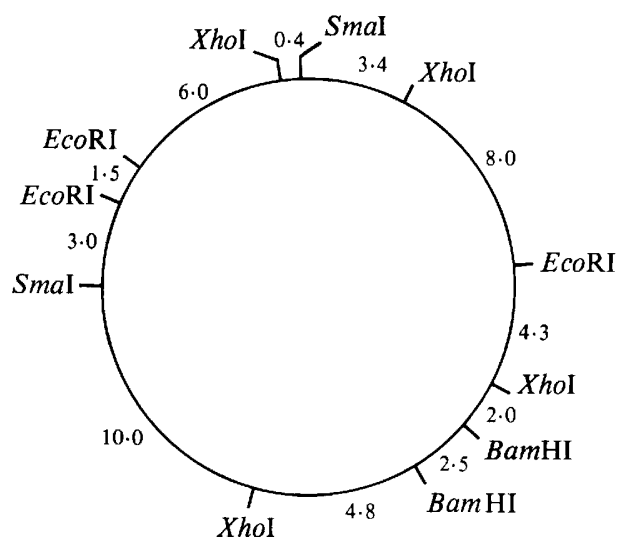

Fig. 1. Partial restriction map of phage A-1 DNA. Lengths of fragments are given in kb.

the $11 \mathrm{~kb}$ long $S m a \mathrm{I}$ fragment and subsequent digestion with EcoRI resulted in three fragments $6.4,3$ and $1.5 \mathrm{~kb}$ long; (b) isolation of the $18 \mathrm{~kb} E c o$ RI fragment and digestion with SmaI gave two fragments 11.5 and $6.4 \mathrm{~kb}$ long; (c) isolation of the large EcoRI fragment and digestion with Bam HI give three fragment $18,6.4$ and $2.5 \mathrm{~kb}$ long (data not shown).

Electron microscopy. The length of the fully extended A-1 DNA molecule, as determined by conventional electron microscopy, is $13.8 \mu \mathrm{m} \pm 5 \%$ (mean of 50 molecules). This value corresponds to a molecular weight of $28 \times 10^{6}$, which is in reasonable agreement with the molecular weight of about $30 \times 10^{6}$ estimated from the results of the restriction analysis. We have been unable to detect any circular molecules in heated $\left(75^{\circ} \mathrm{C}\right.$ for $\left.5 \mathrm{~min}\right)$ or non-heated specimens. Possibly, most of the cohesive hydrogen bonded ends pulled apart during preparation for electron microscopy, as described for $\lambda$ DNA (Thomas \& Davis, 1975) and for the actinophages SH10, SH11 and SH12 DNA (Klaus et al., 1979).

The authors are grateful to Mrs Wilhelmine Hellmann for excellent technical assistance, and to Mrs Patricia Casiano for typing the manuscript.

\section{REFERENCES}

ASAI, T. (1968). Acetic Acid Bacteria: Classification and Biochemical Activities. Tokyo: University of Tokyo Press.

Klaus, S., Triebel, H., Hartmann, M., Walter, A., Walter, F., Zopel, P. \& BAR, H. (1979). Molecular characterization of the genomes of actinophages SH3, SH10, SH11, and SH12 infecting Streptomyces hygroscopicus. Molecular and General Genetics 172 , 319-327.

KLEINSCHMidT, A. K. (1968). Monolayer techniques in electron microscopy of nucleic acid molecules. Methods in Enzymology 12, 361-377.

Maniatis, T., Fritsch, E. F. \& Sambrook, J. (1982). Molecular Cloning: a Laboratory Manual. Cold Spring Harbor, NY: Cold Spring Harbor Laboratory.

Robakis, N. K., Palleroni, N. J., Despreaux, C. W.,
Boublik, M., Baker, C. A., Churn, P. J. \& Claus, G. W. (1985). Isolation and characterization of two phages for Gluconobacter oxydans. Journal of General Microbiology 131, 2467-2473.

Schocher, A. T., KuHN, H., Schindler, B., Palleroni, N. J., Despreaux, C. W., Boublik, M. \& Miller, P. A. (1979). Acetobacter bacteriophage A-1. Archices of Microbiology 121, 192-197.

Thomas, M. \& Davis, R. W. (1975). Studies on the cleavage of bacteriophage lambda DNA with EcoRI restriction endonuclease. Journal of Molecular Bio$\log y$ 91, 315-328.

WARD, G. W. (1967). Production of gluconic acid, glucose oxidase, fructose and sorbose. In Microbial Technology, pp. 200-221. Edited by H. J. Peppler. New York: Reinhold Publishing Corp. 